\title{
PENGOLAHAN NILAM HASIL TUMPANG SARI DI TASIKMALAYA
}

\author{
(Processing of Nilam Cultivated Under Intercropping System \\ in Tasikmalaya)
}

\author{
Oleh/By: \\ Gusmailina, Zulnely \& E. Suwardi Sumadiwangsa
}

\begin{abstract}
The role of non-wood forest products (NWFP) is worth to develop in supporting the activities as well as welfares of the community residing around the forest, and concurrently securing its sustainability. Forest management should be directed to produce more NWFP, thereby creating job opportunity and generate income to local community

Nilam is now being one of the most favourable crops cultivated on agricultural and estate plantation through intercropping scheme. This new fenomenon could be adopted and implied in managing forest plantation. An exploratory research bas been conducted in Pagersari village, Tasikmalaya, West Java, to examine quality and yield of nilam cultivated under intercropping system. Rate of biomass production, local price and conventional oil processing were studied through field surveys, whereas improvement on oil processing was accomplished in laboratory.

Results revealed that nilam cultivated under intercropping could produce green leaves of 75-100 tons per hectar or equivalent to $15-20$ tons of leaves in dry weight. Those quatities were sold to local merchants at $R p 500$ per $\mathrm{kg}$ for green leaves, or $R p 2,500$ per $\mathrm{kg}$ of dry leaves. In all, it could generate income of Rp 37.5-50 millionsper hectar.

Qualities and yield of oil from nilam cultivated in intercropping system was comparable to those cultivated in monoculture one. Alcohol patchouli content in the oil range about 26.0-39.5 percent and even raised to 41.0-49.7 percent after distillation, with the oil recovery of 2.4-5.0 percent. The community in Tasikmalaya revealed their enthusiasms to extend the area of nilam plantation, particularly after the distillation factory was established in Pager Ageung.
\end{abstract}

Keywords: Nilam, intercropping system, oil yield and qualities

\section{ABSTRAK}

Peran hasil hutan bukan kayu (HHBK) dalam menunjang kegiatan dan kesejahteraan masyarakat sekitar hutan perlu dikembangkan. Pengelolaan hutan perlu diarahkan tidak hanya sebagai penghasil kayu tetapi juga sebagai penghasil HHBK yang dapat membuka lapangan 
perkerjaan dan penghasilan bagi masyarakat lokal dengan tetap memperhatikan faktor ekologis. Salah satu program untuk memcapai partisipasi aktif masyarakat dalam pengelolaan hutan yang lestari adalah meningkatkan peran HHBK yang mampu meningkatkan kegiatan dan kesejahteraan masyarakat lokal sekitar hutan. Salah satu komoditi HHBK yang perlu dikembangkan adalah pengusahaan nilam secara tumpang sari terutama pada lahan kawasan hutan, sehingga dapat mendukung optimalisasi penggunaan lahan.

Data, informasi serta contoh uji (daun dan minyak nilam) dikumpulkan dari kampung Pager Ageung, Desa Pager Sari, Kota Tasikmalaya, Jawa Barat yang ditanam secara tumpang sari dengan tanaman pertanian dan perkebunan pada kebun campuran. Hasil pengamatan di lapangan menunjukkan bahwa produktivitas nilam yang ditanam secara tumpang sari di Tasikmalaya sebesar $4 \mathrm{~kg} /$ rumpun/panen dengan hasil DNB (daun nilam basah) sekitar 75-100 ton/ha atau sama dengan 15-20 ton DNK (daun nilam kering) per hektar sekali panen lalu dijual ke pedagang dengan harga Rp 500/kg basah, dan Rp 2.500/kg kering, dengan nilai jual sekitar Rp 37,5-50 juta/ha. Usaha ini dikelola oleh Kelompok Tani Mitra Usaha Jaya, proses penyulingan dengan cara uap panas.

Kualitas dan rendemen minyak yang ditanam secara tumpang sari tidak kalah bagus dengan kualitas minyak yang ditanam secara monokultur. Kadar Patchouli berkisar antara 26-39,5\%, bahkan yang disuling di laboratorium berkisar antara $41-49,7 \%$, dengan rendemen berkisar antara 2,4-5\%. Masyarakat sekitar kota Tasikmalaya semakin berminat untuk memperluas areal penanaman nilam terutam sejak adanya pabrik penyulingan di Pager Ageung, demikian juga pihak kehutanan dan PT Perhutani. Oleh sebab itu pengusahaan nilam secara tumpang sari di lahan kawasan hutan perlu dijadikan bahan pertimbangan kebijakan bagi pengelola dan pengusahaan hutan tanaman.

Kata kunci: Nilam, tumpang sari, rendemen dan kualitas

\section{PENDAHULUAN}

Pola tanam merupakan salah satu upaya manipulasi lingkungan yang dapat berpengaruh terhadap produktivitas tanaman. Pengaruh dapat bersifat menguntungkan, namun juga dapat merugikan baik terhadap produktivitas maupun terhadap kualitas dan kuantitas produksi. Pola tanam akan berpengaruh terhadap produksi daun, rendemen dan mutu minyak nilam (Wahid, 1992). Beberapa sistem pola tanam telah diterapkan di beberapa areal sentra produksi nilam di Indonesia. Idealnya penentuan dan penerapan sistem pola tanam nilam telah ditentukan oleh beberapa faktor utama antara lain lingkungan biotik, abiotik, dan sistem pemrasaran nilam. Selain itu menurut Wahid (1992) yang perlu dipertimbangkan adalah penentuan pola tanam antara tanaman pokok dan tanaman sela antara lain: (1) aspek tidak adanya sifat antagonis dan saling merugikan terutama dalam perebutan hara, cabaya, air dan $\mathrm{CO}_{2}$; (2) tidak memiliki jenis hama dan penyakit yang sama; dan (3) memiliki sifat simbiotik saling menguntungkan dalam memenubi kebutuhan hara dan menekan serangan hama penyakit (Wahid, 1992). Selain itu faktor ketahanan tanaman terhadap kekeringan juga menjadi dasar pertimbangan dalam penyusunan pola tanam. Dengan demikian sumber daya alam yang terbatas dapat dimanfaatkan secara maksimal (Soenardi dan Romli, 1994). 
Penanaman nilam sebagai tanaman tumpang sari pada lahan hutan, merupakan upaya optimalisasi pemanfaatan sumber daya lahan. Lahan kosong diantara tanaman pokok kehutanan dimanfaatkan untuk jenis tanaman segera yang dapat menghasilkan dalam waktu singkat, diantaranya tanaman nilam (Pogostemon cablin). Hal ini merupakan pengelolaan hutan yang diarahkan untuk menghasilkan kayu sekaligus memperoleh hasil hutan bukan kayu (HHBK). Program ini diharapkan dapat membuka lapangan pekerjaan dan penghasilan bagi masyarakat lokal dengan tetap memperhatikan faktor ekologis. Meningkatkan peran HHBK adalah salah satu program partisipasi aktif masyarakat untuk menigkatkan kegiatan dan kesejahteraan masyarakat lokal sekitar hutan untuk mencapai pengelolaan hutan yang lestari (Silva dan Attar, 1995 dalam Wahid,1992; Arnold dan Perez, 1998).

Pemilihan sistem pola tanam tumpang sari dengan tanaman kehutanan sebagai tanaman pokok merupakan alternatif yang perlu dikembangkan dan diperluas penanamannya, karena melalui sistem ini akan meningkatkan pendapatan dan kesejahteraan petani nilam serta dapat menekan perladangan berpindah yang disinyalir sebagai salah satu penyebab kerusakan hutan. Selain itu penanaman nilam di antara tanaman kehutanan adalah cara efisien dalam pemanfaatan lahan, diversifikasi komoditi, kesuburan lahan maupun pengendalian hama penyakit (Silva dan Attar, 1995 dalam Wahid,1992). Penanaman nilam secara tumpang sari merupakan salah satu cara antisipasi mengingat peningkatan jumlah penduduk yang makin tinggi sementara lahan makin terbatas, juga adanya era globalisasi dengan perdagangan bebas menuntut sistem budidaya nilam yang efisien dan berkelanjutan. Tanaman nilam yang mampu beradaptasi dengan naungan memungkinkan petani memperoleh nilai tambah persatuan luas dalam waktu yang singkat dengan tanaman pokok yang berumur panjang. Dengan demikian perlu diketahui produktivitas nilam yang ditanam secara tumpang sari khususnya dengan tanaman kehutanan, produksi minyak, sekaligus kualitas minyak yang diperoleh.

Tulisan ini menyajikan informasi tentang pengelolaan nilam yang ditanam secara tumpang sari yang dilakukan oleh masyarakat/petani dan penyuling nilam di Tasikmalaya, serta mutu dan kualitas minyak yang dihasilkan. Informasi ini diharapkan menjadi bahan pertimbangan untuk program pengembangan nilam di lahan kawasan hutan, sehingga selain dapat mengoptimalkan penggunaan lahan, juga dapat meningkatkan/menambah pendapatan masyarakat sekitar hutan.

\section{METODOLOGI}

\section{A. Lokasi}

Data, informasi serta contoh uji (daun dan minyak nilam) dikumpulkan dari kampung Pager Ageung, Desa Pager sari, Kota Tasikmalaya, Jawa Barat. Pengujian daun dan minyak serta analisis data dilakukan di laboratorium Kelti Pengolahan Hasil Hutan Bukan Kayu, Puslitbang Teknologi Hasil Hutan, dan Laboratorium Pengolahan Hasil dan Keteknikan BALITTRO, Bogor. 


\section{B. Bahan dan Peralatan}

\section{Bahan}

Bahan contoh uji adalah : minyak dan bagian tanaman nilam yang terdiri dari daun, batang, dan ranting tanaman. Minyak nilam yang dianalisis berasal dari hasil penyulingan oleh masyarakat dan hasil penyulingan di laboratorium.

\section{Peralatan}

Peralatan pokok yang digunakan adalah : ketel suling volume $2 \mathrm{~kg}$ bahan kering. Ketel ini berbentuk silinder yang terbuat dari bahan stainless steel untuk menghindari terjadinya reaksi antara minyak nilam dengan logam-logam. Pada bagian atas ketel terdapat lubang yang dapat dihubungkan dengan pipa-pipa yang akan mengalirkan uap dan minyak nilam yang dilengkapi dengan pendingin. Proses penyulingan menggunakan kompor berbahan bakar gas. Untuk mengukur kadar air bahan baku digunakan alat Aufhauser. Selain itu digunakan juga beberapa alat kaca/gelas sebagai alat untuk pengujian minyak nilam.

\section{Prosedur Kerja}

\section{Persiapan bahan baku}

Bagian tanaman nilam yang disuling biasanya campuran antara batang, daun dan ranting. Sebelum disuling dikeringkan dahulu hingga mengandung kadar air sekitar 12$15 \%$, lalu dipotong-potong/dirajang hingga berukuran $2-5 \mathrm{~cm}$. Perajangan juga dapat dilakukan sebelum dikeringkan. Pengeringan dilakukan dengan matahari selama 4 hari, lalu diangin-anginkan hingga tercapai kadar air yang diinginkan.

\section{Penyulingan}

Teknik penyulingan yang dipakai adalah sistem kukus, prinsip penyulingan cara ini dengan menggunakan tekanan uap rendah. Cara ini bahan yang disuling tidak berhubungan langsung dengan air. Bahan diletakkan di atas piringan yang terbuat dari plat seng yang diberi lubang. Setelah air mendidih uap air akan keluar melalui lubanglubang dan terus mengalir melalui sela-sela bahan. Bersama uap air akan ikut terbawa minyak nilam yang dikandung bahan. Uap ini mengalir ke pipa yang dilengkapi dengan pendingin sehingga akan berkondensasi menjadi air dan minyak. Karena perbedaan poloritas dan berat jenis, air akan terpisah dari minyak. Kemudian air dan minyak dipisahkan lalu dihitung volumenya. Komponen bahan yang diuji adalah : daun, batang/ranting, dan campuran daun dan batang/ranting. Waktu penyulingan yang dicoba adalah 4, 6, 8 jam untuk masing-masing komponen yang diuji.

\section{Analisis kadar air bahan dan sifat fisiko kimia minyak nilam}

Kadar air bahan ditetapkan sebelum bahan disuling dengan menggunakan Aufhauser, atau dikenal juga penetapan kadar air dengan cara Xilol atau Ksilena (Chon dan Ta'minuddin, 11978); Penetapan sifat fisiko kimia antara lain : bobot jenis $\left(25 / 25^{\circ}\right.$ C), index bias $\left(25^{\circ} \mathrm{C}\right)$, putaran optik, kelarutan dalam alkohol $(90 \%)$, bilangan asam, dan 
bilangan ester. Penetapan sifat fisiko kimia minyak nilam ini dilakukan menurut Chon dan Ta'minuddin (1978); Analisis patchouli alkohol menggunakan GLC (Gas Liquid Chromatografi).

\section{HASIL DAN PEMBAHASAN}

\section{A. Lapangan}

\section{Profil usaha kecil nilam di Tasikmalaya}

Usaha tanaman nilam terletak di kampung Pageurageung, desa Pager Sari, Tasikmalaya. Usaha ini dikelola oleh Kelompok Tani Mitra Usaha Jaya. Luas areal penanaman tahun 2002 seluas 84 ha pada ketinggian 400 sampai $540 \mathrm{~m}$ dari permukaan laut, sedangkan pada tahun 2003 penanaman nilam akan diperluas menjadi $200 \mathrm{ha}$.

Bibit awal didatangkan dari Balittro, Bogor, jenis Aceh, varietas Lhokseumawe dan Sigli. Kebanyakan nilam ditanam di kebun-kebun campuran, di sawah yang ditanam secara tumpang sari dengan tanaman palawija, atau tanaman pisang. Nilam yang ditanam secara tumpang sari dengan kacang merah ditanam dengan jarak tanam 0,5 x $1 \mathrm{~m}$. Umumnya kebutuhan bibit per ha yang ditanam secara tumpang sari berkisar 20.000 batang/ha, sedangkan nilam yang ditanam secara monokultur murni membutuhkan bibit sekitar $25-30.000$ batang/ha. Penanaman pertama nilam diberi pupuk kandang atau kompos sebanyak 1 piring setiap lobang (kedalaman lobang tanam $20 \mathrm{~cm}$ ), kemudian bibit ditanam miring. Pada umur 3 bulan atau menjelang 4 bulan diberi pupuk kimia Urea/NPK dan KCL sebanyak satu sendok makan per rumpun.

Nilam yang ditanam secara tumpang sari dengan tanaman kehutanan saat ini tidak ada (sudah habis). Penanaman nilam secara tumpang sari dengan tanaman pokok Jati di Tasikmalaya, terakhir tahun1996. Hingga sekarang belum ada penanaman lagi. Hal ini disebabkan karena masalah pemasaran yang tidak lancar pada waktu itu sehingga masyarakat tidak berminat untuk meneruskan usaha ini. Namun hal ini menjadi pemikiran kembali baik bagi pihak dinas Kehutanan dan Perkebunan maupun PT. Perhutani sebagai pemilik lahan kawasan, mengingat saat ini pemasaran nilam yang cukup mudah. Nilam dapat dipasarkan dalam keadaan basah seharga $R p 500 / \mathrm{kg}$, sedangkan dalam keadaan kering (kadar air 12 - 15\%) dipasarkan dengan harga $\mathrm{Rp} 2.500 / \mathrm{kg}$. Sedangkan minyak nilam dipasarkan antara Rp 150.000 ,- sampai Rp 200.000/kg tergantung dari kualitas minyak nilam. Analisis awal Patchouli alkohol minyak nilam yang diolah masyarakat sekitar 30 , sedangkan BJ minyak nilam 0,94.

Panen nilam dilakukan ketika tanaman berumur 6 bulan, untuk selanjutnya dapat dipanen setiap 3-4 bulan. Produksi DNB (daun nilam basah) sekali panen sebesar $4 \mathrm{~kg}$ / rumpun, sedangkan per hektar diperoleh DNB sekitar 75100 ton. Jika dikonversi menjadi DNK akan diperoleh sekitar 15-20 ton/ha dengan nilai jual sekitar Rp 37,5 juta 50 juta. Selama ini masyarakat Tasikmalaya belum mengolah nilam menjadi minyak. Jadi nilam kering dijual ke pedagang yang datang ke lokasi. Perusahaan yang sering membeli nilam dari Tasikmalaya ini dalam keadaan basah atau kering adalah PT. Jasula Wangi Jakarta. Namun pada tahun 2002 mengingat besarnya permintaan minyak nilam 
dari Abudabi, pemerintah Kota Tasikmalaya memberikan seperangkat sarana penyulingan sistem uap (steam) sumbangan Departemen Perindustrian dan Perdagangan yaitu terdiri dari 20 ketel penyulingan dengan kapasitas $50 \mathrm{~kg}$ bahan kering yang disusun secara paralel. Boiler yang menjadi sumber uap kemudian dialirkan ke masing-masing ketel berkapasitas 200 liter yang dirancang secara otomatis dengan waktu suling selama 6 jam. Hasil uji coba penggunaan alat ini menghasilkan rendemen minyak sebesar $2 \%$.

Masyarakat mengusahakan nilam sebagian besar secara sampingan, selain tanaman pokok lainnya. Saat ini masyarakat mulai menunjukkan minat yang cukup besar untuk menanam nilam. Selama ini nilam hanya ditanam oleh sebagian dari anggota kelompok tani. Nilam yang diusahakan dijual dalam bentuk basah atau kering ke Kuningan atau pembeli yang datang ke lokasi namun setelah adanya pabrik penyulingan minyak nilam di Tasik-malaya, masyarakat menjadi lebih berminat untuk menanam nilam dilahanlahan kosong.

Bagi petani yang sudah mencoba membudi-dayakan nilam, mengemukakan usaha ini mendatangkan nilai tambah yang baik dan lumayan, sekalipun hanya diusahakan secara sampingan. Pendapatan jadi bertambah dan kesejahteraan jadi meningkat, dapat menjamin penghidupan dan pendidikan bagi keluarga dan anak hingga ke perguruan tinggi. Hanya saja semua peningkatan kesejahteraan penghidupan secara kualitatif, dengan kata lain petani belum dapat memastikan jumlah nilai rupiah keuntungan yang diperoleh. Yang pasti usaha nilam sangat memberi peluang untuk peningkatan taraf hidup, asal ditekuni.

\section{Prospek dan manfaat regional wilayah}

Minyak nilam merupakan komoditas ekspor, sehingga akan memberikan kontribusi bagi pemasukan devisa negara. Dengan adaya perjanjian kerjasama antara Pemerintah Kota Tasikmalaya sebagai produsen minyak nilam dengan Abudabi, akan meningkatkan pendapatan daerah. Pajak yang diperoleh dari hasil usaha setiap tahunnya memberikan kontribusi yang cukup besar bagi pembangunan daerah. Dari segi pengembangan wilayah keberadaan usaha ini dapat menjadi salah satu pusat kegiatan perekonomian subsektor pertanian, perkebunan, maupun kehutanan yang akan memberikan dampak positif bagi pengembangan kegiatan pembangunan wilayah.

Di sektor kehutanan, tumpang sari nilam merupakan salah satu bentuk pengembangan yang efisien dan efektif. Pengelola hutan sebagai inti menyediakan bibit, serta sarana produksi lainnya, lalu masyarakat sekitar hutan sebagai pekerja. Hasil yang diperoleh kemudian dibeli oleh pihak pengelola hutan untuk diolah atau dipasarkan.

Keberadaan usaha terpadu antara budidaya dan industri penyulingan minyak nilam di Tasikmalaya ini diharapkan akan merangsang masyarakat utuk menciptakan bidang usaha lainnya sebagai pengaruh ganda (multiplier effect). Mengingat minyak atsiri dari nilam merupakan salah satu andalan ekspor Indonesia terbesar di dunia. Berdasarkan laporan Market Study Essential Oils and Oleoresin (ITC), produksi nilam dunia mencapai 500550 ton per tahun (Intisari On Line, 2001). Produk atsiri dunia yang didominasi Indonesia, antara lain nilam, serai wangi, minyak daun cengkeh, dan kenanga. Minyak nilam Indonesia sangat digemari pasar Amerika dan Eropa. Terutama 
digunakan untuk bahan baku industri pembuatan minyak wangi (sebagai pengikat bau atau fixative parfum), kosmetik, dan lain-lain.

\section{B. Laboratorium}

\section{Rendemen minyak nilam}

Rendemen minyak nilam hasil penyulingan di laboratorium HHBK yang tertinggi berasal dari daun yaitu mencapai $5,13 \%$ per berat kering oven dengan waktu penyulingan 4 dan 6 jam, yang terendah diperoleh dari batang dan ranting sebesar 0,6\% selama 6 jam, sedangkan campuran daun dan batang/ranting menghasilkan rendemen minyak sebesar 2,99\% dengan waktu penyulingan 8 jam. Hasil selengkapnya dapat dilihat pada Tabel 1.

Pada Tabel 1 dapat diketahui bahwa komponen tanaman yang banyak menghasilkan minyak adalah daun, rendemen mencapai 5,13\%. Dari beberapa publikasi diketahui bahwa rendemen yang mencapai 5\% jarang ditemukan. Karena kenyataannya dilapangan bahan yang disuling tidak hanya daun, tetapi termasuk juga batang dan ranting. Rendemen minyak yang diperoleh dari komponen campuran ini sebesar 2,99\%. Hasil yang diperoleh lebih tinggi jika dibandingkan dengan rendemen minyak nilam yang dihasilkan dari hasil uji coba alat penyulingan oleh Kelompok Tani Mitra Usaha Jaya, Tasikmalaya, sebesar $2 \%$. Hal ini mungkin disebabkan karena beberapa faktor antara lain : kadar air bahan, alat dan teknik penyulingan, juga cara pengambilan contoh. Hal ini juga dijelaskan oleh Guenther (1949 dalam Wahid 1992), bahwa rendemen dan mutu minyak nilam yanag dihasilkan selain ditentukan oleh jenis, umur tanaman dan proses pengeringan juga dipengaruhi oleh cara penyulingan. Rendemen dan mutu minyak nilam juga dapat dipengaruhi oleh lamanya penyulingan (Dummond, 1960 dalam Wahid, 1992 dan dalam Rusli, 2002).

Tabel 1. Rendemen minyak nilam hasil tumpang sari asal Tasikmalaya Table 1. Oil yielded from Tasikmalaya intercropped nilam plants

\begin{tabular}{|c|c|c|c|c|c|}
\hline \multirow[t]{2}{*}{$\begin{array}{c}\text { Bagian } \\
\text { tanaman } \\
\text { (Part of plant) }\end{array}$} & \multirow{2}{*}{$\begin{array}{c}\text { Waktu } \\
\text { penyulingan } \\
\text { (Distillation } \\
\text { time) (bour) }\end{array}$} & \multirow{2}{*}{$\begin{array}{c}\text { Kadar air bahan } \\
\text { (Material water } \\
\text { content }), \%\end{array}$} & \multirow{2}{*}{$\begin{array}{c}\text { Volume } \\
\text { minyak } \\
(\text { Oil volume })^{1)}\end{array}$} & \multicolumn{2}{|c|}{$\begin{array}{c}\text { Rendemen minyak } \\
(\text { Oil yield }), \%^{2)}\end{array}$} \\
\hline & & & & Laboratory & Tasikmalaya \\
\hline Daun (leaf) & $\begin{array}{l}4 \\
6 \\
8 \\
\end{array}$ & 18,15 & $\begin{array}{l}21,0 \\
21,0 \\
20,0\end{array}$ & $\begin{array}{l}5,13 \\
5,13 \\
4,87 \\
\end{array}$ & - \\
\hline $\begin{array}{l}\text { Batang } \\
\text { (Stem) }\end{array}$ & $\begin{array}{l}4 \\
6 \\
8 \\
\end{array}$ & 21,41 & $\begin{array}{l}1,2 \\
2,5 \\
1,5 \\
\end{array}$ & $\begin{array}{l}0,305 \\
0,64 \\
0,38\end{array}$ & - \\
\hline $\begin{array}{l}\text { Campuran } \\
\text { (Mixed) }\end{array}$ & $\begin{array}{l}4 \\
6 \\
8 \\
\end{array}$ & 16,55 & $\begin{array}{c}10 \\
8 \\
12,5 \\
\end{array}$ & $\begin{array}{l}2,40 \\
1,92 \\
2,99\end{array}$ & 2 \\
\hline
\end{tabular}

Keterangan (Remarks): ") Volume minyak/500 gram contoh (Oil volume/500 g)

${ }^{2)}$ Rendemen minyak/berat kering oven, \% (The oil yield/oven dry weight, \%) 
Umumnya kandungan minyak nilam dari daun berkisar 2,5 - 4\% (Dummond, 1960 dalam Rusli, 2002), sedangkan menurut Azwar (1968) penyulingan masyarakat secara tradisional dengan kapasitas kecil-kecilan diperoleh rendemen minyak dari daun sekitar 2,74\%. Sieng (1962) dalam Azwar (1968) melaporkan bahwa penyulingan cara uap langsung dengan tekanan menghasilkan rendemen minyak 2,5\%. Tingginya perolehan rendemen minyak nilam hasil penyulingan di laboratorium, mungkin disebabkan karena kapasitas alat suling yang kecil ( $2 \mathrm{~kg}$ bahan kering), sehingga panas/suhu dalam ketel lebih merata. Pada Gambar 1 dapat dilihat perolehan rendemen minyak nilam yang disuling di laboratorium, yang menunjukkan bahwa bagian daun lebih banyak menghasilkan minyak dibandingkan bagian batang atau campuran.

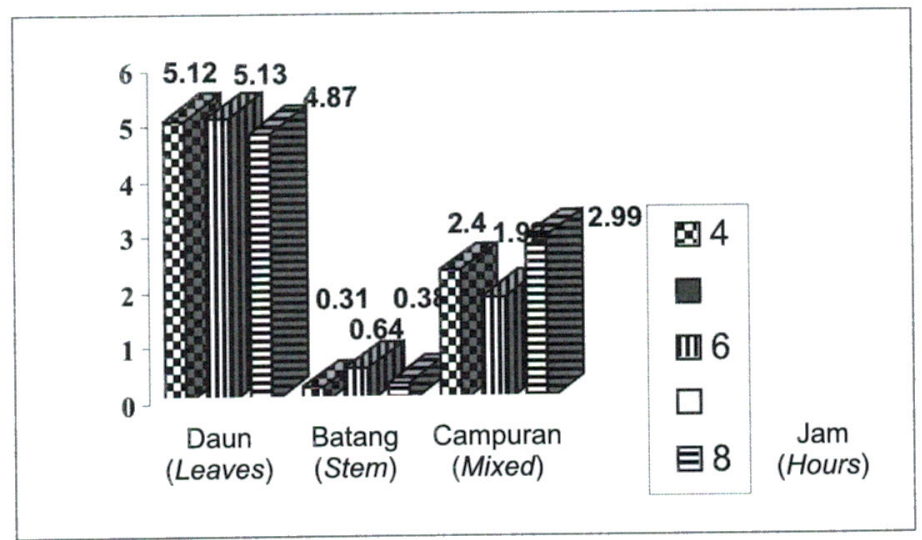

Gambar 1. Perbandingan rendemen minyak nilam berdasarkan komponen tanaman dan lama penyulingan

Figure 1. Yield comparison of nilam oil based on component materials and distilling time

Rendemen minyak dari nilam yang ditanam secara tumpang sari, ternyata tidak jauh berbeda dengan nilam yang ditanam secara monokultur yaitu sekitar $0,9-1,3 \%$ (Bruns, 1978 dalam Rusli, 2002). Artinya tumpang sari nilam dengan palawija tidak menjadi masalah, namun tumpang sari dengan tanaman keras/tanaman kehutanan sebaiknya ketika tanaman pokok masih muda atau pada saat awal tanam dengan naungan di bawah $80 \%$.

Untuk pertumbuhan optimal, nilam perlu cukup sinar matahari. Namun bisa tumbuh baik di tempat yang agak terlindung. Karena itu nilam dapat dianjurkan ditanam secara tumpang sari dengan tanaman lain. Di lereng kaki Gunung Ceremai (200 - $1.000 \mathrm{~m} \mathrm{dpl),} \mathrm{di} \mathrm{daerah} \mathrm{Kuningan} \mathrm{(Jawa} \mathrm{Barat),} \mathrm{tanaman} \mathrm{nilam} \mathrm{ditumpang} \mathrm{sarikan}$ dengan tanaman jagung, bahkan tumbuh baik ditanam disela-sela lamtoro gung, kelapa, atau karet, dan tusam (Pinus merkusii) (Gusmailina dkk., 2002).

Kadar air bahan cukup tinggi berkisar antara 16 sampai 21\%. Hal ini merupakan salah satu faktor penyebab rendemen minyak yang diperoleh menjadi agak rendah. Karena kadar air bahan baku yang optimal dan dianjurkan adalah antara $12-15 \%$. Hal ini mungkin disebabkan oleh kondisi penyimpanan bahan baku. 
2. Sifat fsiko kimia minyak nilam

Sifat fisiko kimia minyak nilam yang diperoleh dapat dilihat pada Tabel 2. Makin lama waktu penyulingan semakin meningkat berat jenis minyak baik pada daun, batang maupun campuran daun dan batang. Hal yang sama juga terjadi pada nilai indeks bias maupun putaran optik. Semua sifat fisiko kimia minyak nilam yang dihasilkan termasuk ke dalam standar SNI (Anonim, 1998).

Tabel 2. Analisis sifat fisiko kimia minyak nilam

Table 2. Analysis on physico-chemical properties of nilam oil

\begin{tabular}{|c|c|c|c|c|c|c|c|}
\hline No. & $\begin{array}{l}\text { Bahan (Material) } \\
\text { Lama Penyulingan } \\
\text { (Distilling time, } \\
\text { bours) }\end{array}$ & $\begin{array}{l}\text { Bobot } \\
\text { Jenis } \\
\text { (Specific } \\
\text { gravity) }\end{array}$ & $\begin{array}{l}\text { Indek bias } \\
\text { (Refractive } \\
\text { index) }\end{array}$ & $\begin{array}{l}\text { Putaran } \\
\text { Optik } \\
\text { (Optical } \\
\text { rotation) }\end{array}$ & $\begin{array}{c}\text { Kelarutan } \\
\text { dalam alkohol } \\
\text { (Solubility in } \\
\text { alcohol) }\end{array}$ & $\begin{array}{l}\text { Bilangan } \\
\text { asam } \\
\text { (Acid } \\
\text { number) }\end{array}$ & $\begin{array}{c}\text { Bilangan } \\
\text { ester } \\
\text { (Ester } \\
\text { number) }\end{array}$ \\
\hline 1 & $\begin{array}{ll}\text { Daun (Leaf) } & 4 \\
& 6 \\
& 8\end{array}$ & $\begin{array}{l}0,9482 \\
0,9557 \\
0,9560\end{array}$ & $\begin{array}{l}1,5045 \\
1,5058 \\
1,5063\end{array}$ & $\begin{array}{r}-46^{\circ} \\
-47^{\circ} 12^{\prime} \\
-53^{\circ} 12^{\prime}\end{array}$ & $\begin{array}{c}1: 8 \\
1: 6: 5 \\
1: 7\end{array}$ & $\begin{array}{l}0,54 \\
0,54 \\
1,50\end{array}$ & $\begin{array}{l}2,49 \\
3,10 \\
2,72\end{array}$ \\
\hline 2 & $\begin{array}{l}\text { Batang } \\
\text { (Stem) }\end{array}$ & $\begin{array}{l}0,9426 \\
0,9447 \\
0,9451\end{array}$ & $\begin{array}{l}1,5054 \\
1,5091 \\
1,5082\end{array}$ & $\begin{array}{c}-45^{\circ} \\
-46^{\circ} 12^{\prime} \\
-47^{\circ} 45^{\prime}\end{array}$ & & $\begin{array}{l}0,48 \\
0,50 \\
1,50\end{array}$ & $\begin{array}{l}1,30 \\
2,86 \\
3,01\end{array}$ \\
\hline 3 & $\begin{array}{ll}\text { Campuran } & 4 \\
(\text { Mix }) & 6 \\
& 8\end{array}$ & $\begin{array}{l}0,9489 \\
0,9554 \\
0,9615\end{array}$ & $\begin{array}{l}1,5054 \\
1,5067 \\
1,5069\end{array}$ & $\begin{array}{l}-45^{\circ} \\
-47^{\circ} 12^{\prime} \\
-49^{\circ} 45^{\prime}\end{array}$ & $\begin{array}{c}1: 2: 5 \\
1: 5: 5 \\
1: 1\end{array}$ & $\begin{array}{l}0,69 \\
2,31 \\
2,92\end{array}$ & $\begin{array}{l}1,33 \\
5,18 \\
4,86 \\
\end{array}$ \\
\hline 4 & $\begin{array}{l}\text { Minyak nilam } \\
\text { hasil pengolahan } \\
\text { masyarakat } \\
\text { (Nilarit } \\
\text { produced by } \\
\text { farmers) } \\
\text { Varietas Aceh } \\
\text { (Aceb variety) } \\
\text { Varietas Jawa } \\
\text { (Java variety) }\end{array}$ & $\begin{array}{l}0,9516 \\
0,9302\end{array}$ & 1,5015 & $\begin{array}{l}-46^{\circ} 12^{\prime} \\
-50^{\circ} 45^{\prime}\end{array}$ & $1: 4: 5$ & 2,27 & 8,59 \\
\hline
\end{tabular}

3. Patchouli oil (Patchouli alkohol)

Patchouli oil adalah nama dagang minyak nilam merupakan standard yang menentukan kualitas dari minyak nilam yang dihasilkan. Secara kimia sering juga disebut sebagai Patchouli alkohol (PA). Berdasarkan aroma PA digolongkan dalam empat jenis mutu yaitu : ordinary dan medium yang merupakan hasil sulingan dari Indonesia dan Singapura, sedangkan golongan special dan extra special merupakan hasil sulingan yang berasal dari Perancis dan Inggeris, dimana penyulingan dilakukan secara tidak langsung dan daun dipilih terlebih dahulu. Kadar PA nilam yang diperoleh dapat dilihat pada Gambar 2. 


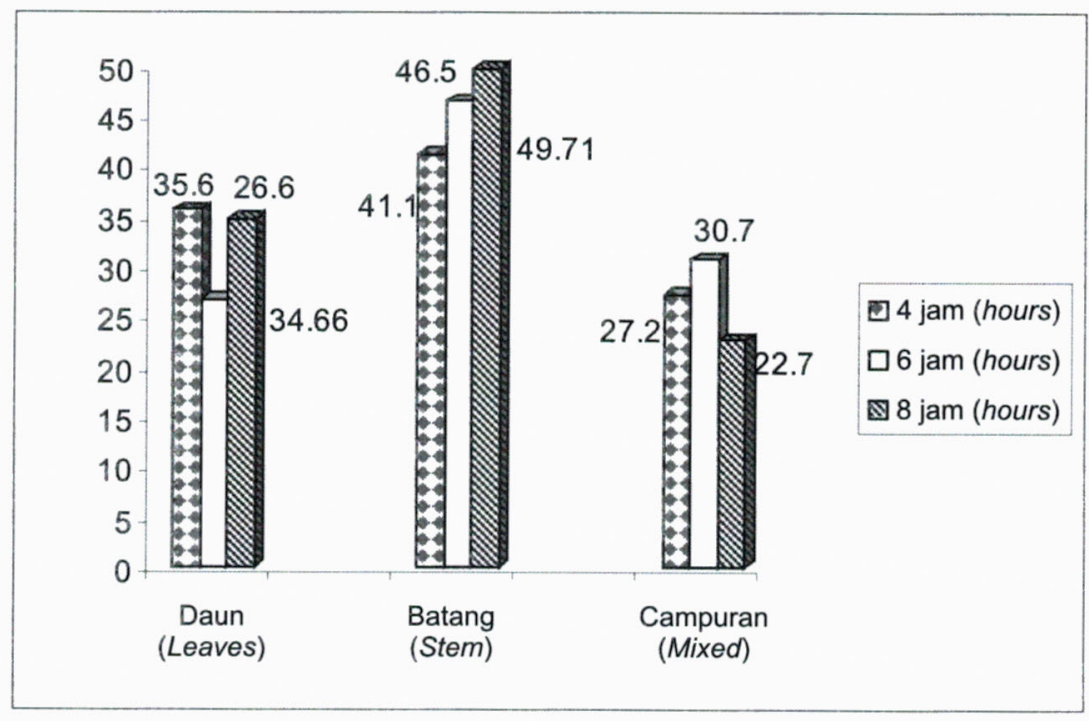

Gambar 2. Perbandingan kadar PA minyak nilam hasil tumpang sari

Figure 2. Comparison of patchouli alcohol (PA) in nilam oil extracted from intercropped plants

Pada Gambar 2 dapat dilihat bahwa ternyata kadar PA nilam tertinggi diperoleh pada bagian batang $(49,71 \%)$ dengan penyulingan selama 8 jam. Ekstraksi batang menunjukkan bahwa makin lama penyulingan, makin tinggi kadar PA yang diperoleh. Sedangkan pada bagian daun lama penyulingan tidak menunjukkan peningkatan kadar PA. Angka PA tertinggi diperoleh pada hasil penyulingan selama 4 jam $(35,60 \%)$, kemudian diikuti waktu penyulingan 8 jam dan 6 jam.

Untuk bahan campuran diperoleh kadar PA tertinggi pada waktu penyulingan 6 jam dengan nilai $30,70 \%$, sedangkan yang terrendah diperoleh pada waktu kondisi penyulingan 8 jam (22,7\%). Kadar PA minyak nilam yang dihasilkan di laboratorium ternyata lebih tinggi jika dibandingkan dengan kadar PA minyak nilam yang disuling oleh masyarakat Tasikmalaya. Juga tidak berbeda dengan kadar PA nilam yang ditanam secara monokultur (Rusli, 2002).

Pada Gambar 2 dapat dilihat bahwa kadar PA minyak nilam yang disuling di Lab. Kelti HHBK lebih tinggi dibanding dengan minyak nilam yang dihasilkan oleh masyarakat Tasikmalaya. 


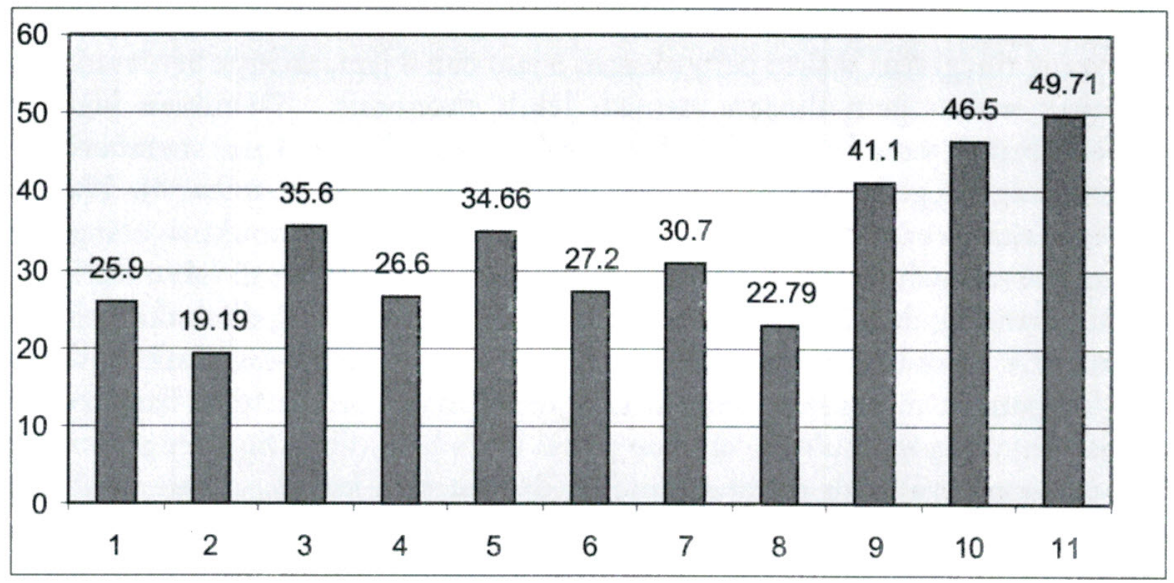

Gambar 3. Kadar PA (Patchouli alcohol) minyak nilam Aceh asal Tasikmalaya yang disuling oleh masyarakat (1 \& 2), dan yang disuling di Lab HHBK $(3 \mathrm{~s} / \mathrm{d} 11)$

Figure 3. Patchouli alcobol (PA) content of Aceb nilam oil processed by local community in Tasikmalaya (1E2) and processed in NWFP laboratory (3-11)

Keterangan Gambar: (1) minyak nilam Aceh hasil penyulingan masyarakat Tasikmalaya; (2) minyak nilam Jawa hasil penyulingan masyarakat Tasikmalaya, $(3,4,5)$ minyak nilam dari daun yang disuling di Lab HHBK selama 4 jam, 6 jam dan 8 jam; $(6,7,8)$ minyak nilam dari komponen campuran daun dan batang yang disuling di Lab HHBK selama 4 jam,6, dan 8 jam; $(9,10,11)$ minyak nilam dari batang dan ranting yang disuling di Lab HHBK selama 4 jam, 6 dan 8 jam

Discription of figure: (1) Aceb nilam oil produced by Tasikmalaya community; (2) Java nilam oil produced by Tasikmalaya community; $(3,4 \mathcal{E} 5)$ nilam oil leaves distilled for consecutively $4,6, E 8$ hours, conducted in the non wood forest products laboratory; $(6,7,8)$ nilam oil distilled from the mixture of nilam leaves and stems for consecutively $4,6, \& 8$ bours, as conducted in the non wood forest products laboratory; $(8,9,10)$ nilam oil distilled from the mixture of nilam stems and twigs for consecutively 4,6 , and 8 hours, as conducted in the non wood forest products laboratory

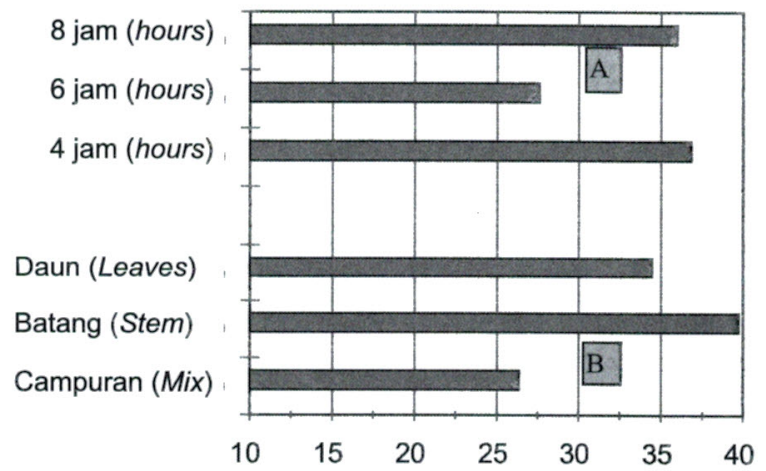

Gambar 4. Perbandingan persentase kadar PA minyak nilam berdasarkan lama penyulingan (A) dan (B) komponen tanaman

Figure 4. Comparison $f$ alcohol patchouli content based on distillation time processed $(A)$ and component of nilam foliage plant (B) 
Berdasarkan Gambar 3, ternyata waktu suling 4 jam sudah memberikan kadar PA minyak yang tinggi dari waktu penyulingan 6 jam dan 8 jam, artinya berdasarkan kadar PA minyak waktu penyulingan menjadi lebih ekonomis. Demikian juga dengan rendemen minyak yang berasal dari daun, waktu penyulingan 4 jam memberikan hasil rendemen yang tinggi dari waktu penyulingan 6 jam dan 8 jam (Gambar 4). Namun jika hal ini digunakan sebagai saran kepada petani pengolah, perlu pembuktian ulang.

Umumnya kualitas dan rendemen minyak yang diperoleh di laboratorium lebih baik jika dibanding dengan kualitas dan rendemen minyak yang dilakukan oleh petani setempat. Di laboratorium teknik penyulingan dilakukan secara kukus, sedangkan petani di lapangan melakukan dengan cara uap panas. Secara teori dan pengalaman beberapa penyuling sebetulnya cara uap panas lebih baik dibanding dengan cara kukus walaupun tekniknya lebih rumit dibanding dengan cara kukus. Oleh sebab itu cara kukus yang dilakukan di laboratorium perlu dicoba dengan kapasitas yang lebih besar.

\section{KESIMPULAN DAN SARAN}

\section{A. Kesimpulan}

\section{Lapangan}

a. Rata-rata produktivitas tanaman nilam sebesar $4 \mathrm{~kg} / \mathrm{rumpun} /$ panen atau sekitar 75 100 ton/ha/panen DNB (daun nilam basah), jika dikonversi ke DNK menjadi 15-20 ton DNK/panen/ha, dengan nilai jual sekitar Rp37,550 juta/ha.

b. Pengolahan pasca panen nilam meliputi penjemuran disinar matahari sekitar 4 jam/hari selama 4-5 hari, kemudian diangin-anginkan sampai kondisi bahan baku siap untuk disuling dengan kadar air sekitar $12-15 \%$.

2. Laboratorium

a. Rendemen minyak nilam yang tinggi diperoleh dari komponen daun sebesar $5,13 \%$ dengan waktu penyulingan 4 dan 6 jam, sedangkan yang terendah dari batang sebesar 0,6\% dengan waktu penyulingan 6 jam. Campuran batang daun sebesar 2,49\% dengan waktu penyulingan 8 jam. Kadar air bahan baku berkisar antara $16-21 \%$;

b. Berat jenis minyak nilam berkisar antara $0,94-0,96$, rata-rata indek bias 1,50 , kelarutan dalam alcohol bervariasi dari 1:1 sampai 1:8, bilangan asam berkisar dari 0,6-2,9, bilangan ester berkisar antara 1-5;

c. Kadar patchouli alcohol (PA) tertinggi yaitu pada batang sebesar $49,7 \%$ dengan waktu penyulingan 8 jam, kadar PA daun sebesar 35,60\% dengan waktu penyulingan $4 \mathrm{jam}$, campuran sebesar 30,7 waktu suling selama 8 jam;

d. Secara keseluruhan minyak nilam yang dihasilkan dilaboratorium lebih baik kualitasnya dibanding dengan kualitas minyak yang dihasilkan oleh masyarakat;

e. Dari hasil yang diperoleh ternyata kualitas minyak yang ditanam secara tumpangsari tidak jauh berbeda (hampir sama) dengan kualitas minyak yang ditanam secara monokultur. 


\section{B. Saran}

Penanaman nilam sebaiknya dikembangkan secara lebih intensif pada program hutan kemasyarakatan, sehingga dapat memberikan manfaat langsung bagi masyarakat di sekitar hutan. Pada program ini pengelola hutan sebagai inti menyediakan bibit, serta sarana produksi lainnya, lalu masyarakat sekitar hutan sebagai pekerja. Hasil yang diperoleh kemudian dibeli oleh pihak pengelola hutan untuk diolah atau dipasarkan.

\section{DAFTAR PUSTAKA}

Anonim. 1998. Monografi nilam. Monograf No 5. Badan Penelitian dan Pengembangan Pertanian. Balai Penelitian Tanaman Rempah dan Obat. Bogor.

Arnold, J.E.M. dan M.R. Perez. 1998. The role of non-timber forest products in conservation and development income from forest. CIFOR-IUCN. Bogor.

Azwar. 1968. Penyulingan minyak patchouli. Karya Sarjana Muda. Akademi Kimia Analisis. PNPR, Nupika yasa, Bogor.

Chon Ahmad dan Ta'minuddin. 1978. Penuntun praktikum khusus. Sekolah Analisis Kimia Menengah Atas. Pusat Pendidikan dan Latihan. Departemen Perindustrian. Bogor.

Gusmailina, Zulnely dan E.S. Sumadiwangsa. 2002. Profil pengusahaan nilam (Pogostemon cablin) pada lahan kawasan hutan di daerah Jawa Barat. (Studi Kasus I: Desa Setianegara, Kabupaten Kuningan). Seminar Hasil Penelitian Hasil Hutan. 2002. Puslitbang Teknologi Hasil Hutan. Bogor.

Intisari On line. 2001. Minyak atsiri, jawaban atas salah satu masalah klasik pertanian Indonesia. Senin, 19 November 2001. PT Cakrawala Pengembangan Agro Sejahtera. Jakarta. http://www.indomedia.com/atsiri.htm.

Rusli, S. 2002. Diversifikasi ragam dan peningkatan mutu minyak atsiri. Makalah pada Workshop Nasional Minyak Atsiri, Oktober 2002. Direktorat Jenderal Industri dan Dagang Kecil-Menengah. Depperindag. Jakarta.

Santoso, H.B. 1994. Bertanam nilam, bahan Industri wewangian. Penerbit Kanisius. Yogyakarta.

Silva, T \& C.K. Attar. 1995. Processing, refinement and value addition of NWFP's. In Report of the Expert Consultation on NWFP's, Yogyakarta, Indonesia. 17-27 Januari 1995. Non-Wood Forest Products 3. FAO. Rome.

Soenardi dan M. Romli. 1994. Pola tanam wijen dan palawija untuk peningkatan penerimaan petani. Pemberitaan Penelitian Tanaman Industri : 20(1-2):16-23. Bogor. 
JURNAL. Penelitian Hasil Hutan Vol. 23 No. 1, Februari 2005: 1-14

Tan, S.H. 1962. Minyak atsiri. Balai Penelitian Kimia. PNPR. NUPIKA-Yasa. Depperindag. Penerbit Kantor Penyuluhan Depperindag. Bogor.

Wahid, P. 1992. Peningkatan tanaman melalui tanaman sela dan tanaman campuran. Proceding Temu Usaha Pengembangan. Hasil Penelitian Tanaman Rempah dan Obat, Oktober 1992. Balittro. Bogor. 